\title{
Nilai-nilai Pendidikan Akhlak dalam Kitab al Barzanji Karya Syaikh Ja'far al Barzanji dan Implementasinya Dalam Pendidikan
}

\author{
RestiAyuNisa $^{1^{\star}}$, danSholeh Hasan ${ }^{2^{\star \star}}$ \\ ${ }^{12}$ STKIP Nurul Huda Sukaraja OKU Timur \\ *resti.ayu@gmail.com, **sholehhasan@stkipnurulhuda.ac.id
}

\begin{abstract}
Abstrak
Penelitian ini bertujuan untuk mengetahui nilai-nilai pendidikan akhlak yang terkandung dalam kitab Al Barzanji karya Syaikh Ja'far Al Barzanji dan implementasi nilai-nilai pendidikan akhlak.Jenis penelitian ini adalah penelitian pustaka atau library research. Jenis data yang digunakan adalah data primer berupa literatur yang berhubungan langsung dengan judul dan data skunder atau data pendukung. Teknik pengumpulan data yang digunakan adalah studi telaah, studi pustaka, dan studi literatur. Teknik analisis data ada.lah deskriptif.

Analisis data penelitian disimpulkan Pertama: Konsep pendidikan akhlak adalah suatu kegiatan yang dilakukan secara sadar dan disengaja untuk memberikan bimbingan, baik jasmani maupun rohani, melalui penamaan nilai-nilai islam, latihan moral, fisik serta menghasilkan perubahan ke arah positif, yang nantinya dapat diaktualisasikan dalam kehidupan, dengan kebiasaan bertingkah laku, berfikir dan berbudi pekerti luhur menuju terbentuknya manusia yang berakhlak mulia, dimana dapat menghasilakan perbuatan atau pengalaman dengan mudah tanpa harus direnungkan dan disengaja atau tanpa adanya pertimbangan dan pemikiran. Kedua: Nilai-nilai pendidikan akhlak yang terkandung dalam kitab Al Barzanji karya Syaikh Ja'far Al Barzanji secara garis besar terbagi menjadi dua bagian, yakni akhlak kepada Allah SWT dan akhlak kepada makhluk. Akhlak kepada Allah meliputi cinta kepada Allah SWT, syukur, berdoa, dan tawadhu, kedua, akhlak kepada makhluk meliputi akhlak kepada Nabi Muhammad SAW, akhlak terhadap diri sendiri meliputi tawadhu, jujur, sabar, iffah dan zuhud, akhlak kepada keluarga meliputi birrul walidain dan akhlak kepada anak, akhlak kepada masyarakat terdiri atas musyawarah, adil, kasih sayang dan pemaaf. Ketiga: Implementasi nilai-nilai pendidikan akhlak dalam kitab Al Barzanji karya Syaikh Ja'far Al Barzanji dalam pendidikan dilakukan melalui penerapan kompetensi inti setiap satuan pembelajaran khususnya kompetensi religius dan kompetensi sosial.
\end{abstract}

Kata Kunci:Nilai-nilai Pendidikan Akhlak, Kitab Al Barzanji, Implementasi, Pendidikan

\section{PENDAHULUAN}

Pendidikan akhlak menempati posisi sangat penting dalam Islam, karena kesempurnaan seseorang tergantung kepada kebaikan dan kemuliaan akhlak seseorang. Hal tersebut sebagaimana dijelaskan Muhammad (2006:54) bahwa, "Manusia yang dikehendaki Islam adalah manusia yang memiliki akhlak yang mulia, manusia yang seperti inilah yang akan mendapatkan kebaikan di dunia dan akhirat". Sementara itu, Imam Ali (dalam Nawawi, 2002:104) mengatakan bahwa "Akhlak adalah sebaik-baik teman".

Akhlak merupakan fondasi yang kokoh bagi terciptanya hubungan baik antara hamba dan Allah SWT atau hablumminallah dan antar sesama manusia atau hablumminannas. Akhlak yang mulia tidak lahir berdasarkan keturunan atau terjadi secara tiba-tiba, akan tetapi membutuhkan proses panjang yakni melalui pendidikan akhlak. Mahmud (2002:11) mengungkapkan, "Banyak sistem pendidikan akhlak, moral dan etika yang ditawarkan, namun banyak juga kelemahan dan kekurangan karena standar tersebut hanya berasal dari manusia sendiri yang ilmu dan pengetahuan sangat terbatas". Konsep pendidikan akhlak dalam Islam menegaskan bahwa segala sesuatu itu dapat dinilai baik dan buruk, terpuji atau tercela, semata-mata berdasarkan Al Qur'an dan Al Hadits. Muhammad (2006:75) mengatakan bahwa "Ajaran akhlak dalam Islam bersumber dari wahyu Allah SWT yang termaktub dalam AI-Qur'an dan Hadits".

Penulis melihat bahwa kisah Nabi Muhammad SAW dalam kitab Al Barzanji memiliki begitu banyak makna tentang pendidikan akhlak yang sangat dalam untuk dijadikan teladan bagi seluruh umat, khususnya umat Islam. Harapan penulis nantinya para pembaca akan bersemangat dalam mengaktualisasikan nilai-nilai pendidikan akhlak dalam kitab maulid Al Barzanji. 


\section{METODE/EKSPERIMEN}

Jenis digunakan dalam penelitian ini adalah penelitian pustaka atau library research. Sudrajat (2005:7) mengatakan, "Studi kepustakaan adalah penelitian dengan teknik pengumpulan data melalui mengadakan studi penelaahan terhadap buku-buku, literatur-literatur, catatan-catatan, dan laporan-laporan yang ada hubungannya dengan masalah yang dipecahkan". Sukmadinata (2015:74) menjelaskan, "Penelitian pustaka atau library research adalah penelitian yang dilakukan dengan cara menghimpun informasi yang relevan dengan topik atau masalah yang akan atau sedang diteliti".

Penelitian pustaka atau library research dilakukan menggunakan teknik content analysis. Sukardi (2012:21) menjelaskan, "Content Analysis adalah penelitian yang bersifat pembahasan mendalam terhadap isi suatu informasi tertulis atau tercetak dalam media massa". Pengertian tersebut menunjukkan bahwa Content Analysis adalah metode meliputi semua analisis menganai isi teks, tetapi di sisi lain Content Analysis juga digunakan untuk mendeskripsikan pendekatan analisis khusus. Content Analysis adalah suatu teknik untuk mengambil kesimpulan dengan mengidentifikasi berbagai karakteristik khusus suatu pesan secara objektif, sistematis, dan generalis.

Analisis data dilakukan dalam penelitian ini adalah analisis nilai-nilai pendidikan akhlak dalam kitab $\mathrm{Al}$ Barzanji karya Syaikh Ja'far Al Barzanji dalam pendidikan. Langkah-langkah menganalisis adalah:

1. Tahap deskripsi yaitu seluruh data dihubungkan persoalan setelah itu dilakukan tahap pendeskripsian. Oleh karena pada penelitian ini data terkumpul berupa satuan semantis seperti kata-kata, frasa, klausa, kalimat, serta hasilnya berupa kutipan-kutipan dari kumpulan data tersebut berisi tindakan, pikiran, pandangan hidup, konsep, ide, gagasan yang terdapat pada kitab Al Barzanji.

2. Tahap klasifikasi yaitu data-data telah dideskripsikan kemudian dikelompokkan menurut kelompoknya masing-masing sesuai dengan permasalahan.

3. Tahap análisis yaitu data-data yang telah diklasifikasikan menurut kelompoknya masing-masing dianalisis menurut struktur kemudian dianalisis lagi dengan metode deskriptif.

4. Tahap interpretasi data yaitu upaya penafsiran dan pemahaman terhadap hasil analisis data.

5. Tahap evaluasi yaitu data-data yang sudah dianalisis dan diinterpretasikan sebelum ditarik kesimpulan begitu saja. Data-data harus diteliti dan dievaluasi kembali agar dapat diperoleh penelitian dapat dipertanggungjawabkan.

6. Penarikan simpulan yaitu penelitian ini akan disimpulkan menggunakan teknik induktif yaitu penarikan kesimpulan berdasarkan dari pengetahuan bersifat khusus, untuk menentukan kesimpulan bersifat umum

Data penelitian dikumpulkan menggunakan metode telaah, dokumentasi dan literatur.

1. Metode Telaah

Sukmadinata (2015:123) menyatakan, "Metode telaah adalah suatu cara pengumpulan data yang teratur berdasarkan pemikiran yang cermat atau bersistem untuk memudahkan melaksanakan penyelidikan, kajian, pemeriksaan terhadap berbagai hal di dalam penelitian serta pengkajian data selanjutnya". Maksud dari metode ini adalah untuk memperoleh keterangan tentang bahasa, struktur nilai dan keterangan atau bahan nyata sebagai dasar kajian atau analisis atau kesimpulan mengenai nilai-nilai pendidikan akhlak dalam kitab Al Barzanji karya Syaikh Ja'far Al Barzanji dalam pendidikan.

2. StudiDokumentasi

Sukmadinata (2015:127) menjelaskan, "Studidokumentasi adalah cara untuk menggali, mengkaji, dan mempelajari sumber-sumber tertulis baik dalam bentuk laporan penelitian, dokumen kurikulum, majalah, jurnal, kliping, maupun media masa". Dokumentasi adalah mencari data mengenal hal-hal atau variabel berupa catatan, transkip, buku, surat kabar, majalah, prasasti, notulen rapat, agenda dan sebagiannya. Penelitian yang digunakan dalam penulisan skripsi ini merupakan penelitian bersifat kepustakaan (Library research) yaitu dilakukan dengan cara membaca dan mempelajari bukubuku, teori-teori, dan literatur atau refrensi berhubungan dengan masalah penelitian guna memperoeh data. Pengumpulan data dan informasi dalam skripsi ini diakukan melalui berbagai sumber dengan metode pengumpulan data kualitatif yaitu studi dokumentasi dan studi literatur.

Dokumentasi merupakan suatu teknik pengumpulan data dengan menghimpun dan menganalisi dokumen baik dokumen tertulis, gambar, maupun elektronik. Metode dokumentasi mencari data mengenai hal-hal atau variabel berupa catatan. Dokumen sebagai sumber data dimanfaatkan 
untuk mengkaji, menafsirkan, untuk meramalkan keadaan suatu objek penelitian. Dokumentasi pada penelitian ini dilakukan dengan cara mengumpulkan berbagai data-data penelitian sesuai maksud judul penelitian yaitu data nilai-nilai pendidikan akhlak dalam kitab Al Barzanji karya Syaikh Ja'far Al Barzanji dalam pendidikan.

3. Studi Literatur

Sukmadinata (2015:129) mengemukakan, "Studi literatur dimaksudkan untuk mengungkapkan berbagai teori-teori relevan dengan pembahasan sedang dihadapi atau diteliti sebagai bahan pembahasan hasil penelitian". Teknik ini diakukan dengan cara membaca, mempelajari, dan mengkaji berbagai literatur berhubungan dengan nilai-nilai pendidikan akhlak dalam kitab Al Barzanji karya Syaikh Ja'far Al Barzanji dalam pendidikan. Hasil studi literatur bisa dijadikan masukan sekaligus landasan dalam menjelaskan maupun merinci masalah penelitian termasuk sumber latar belakang masalah itu diteliti.

\section{HASIL DAN PEMBAHASAN}

Hasil

Nilai-Nilai Pendidikan Akhlak yang Terkandung dalam Kitab Al Barzanji Karya Syaikh Ja'far Al Barzanji adalah sebagai berikut:

\section{A. Nilai Akhlak Kepada Allah}

\section{Cinta Kepada Allah}

Kalimat "Ada Surga Di Rumahmu" merupakan tagline Ustad Ahmad Al-Habsyi yang selalu meyakini bahwa surga itu bukanlah tempat yang jauh melaikan ada di rumah sendiri. Allah sendiri menyebutkan bahwa ridha Allah tergantung dari ridha orang tua. Sudah seharusnya bahwa memuliakan orang tua merupakan suatu kewajian yang mutlak harus dijaga. Hal ini lah yang mendasari Ustadz Ahmad Al-Habasyi untuk mengajarkan ilmu surga di dalam rumah.

Cinta kepada Allah merupakan bentuk manifestasi keridhaan manusia kepada Allah sebagai Tuhan yang patut disembah. Nilai cinta kepada Allah pada kitab Al Barzanji dapat dicermati pada kalimat berikut:

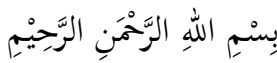

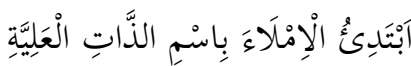

$$
\begin{aligned}
& \text { مُسنتَدِرًَا فَيْضَ الْبَرَكَاتِ عَلَي مَا اَنَا لَهُ وَاوَولاهُ }
\end{aligned}
$$

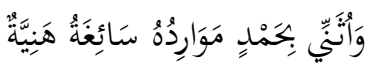

Artinya:

Dengan menyebut nama Allah yang maha pengasih lagi maha penyayang.

Aku memulai membacakan (kitab ini) dengan menyebut Nama Dzat Tuhan yang Maha Tinggi.

Seraya memohon limpahan berkah dan restu-Nya atas apa yang telah saya peroleh.

Dan saya memanjatkan puja dan puji, dengan puji-pujian yang tiada hentiny. (Zuhri, 2012:7).

Bait isi kitab Al Barzanji tersebut, Syekh Ja'far memulai penulisan yakni penulisan tentang kisah kelahiran Nabi, perjalanan hidup dan semua yang mencakup tentang Nabi Muhammad SAW. dengan menyebut zat yang tinggi drajat-Nya dengan segala sifat yang sempurna. Nawawi (2015:4) menjelaskan, "Allah telah menganugerahi keberkahan kepada sesuatu yang dikehendaki dan tidak dikehendaki dan diiringi dengan memuji kepada Allah SWT dengan lisan dan seluruh anggota badan atas segala kemudahan yang menggembirakan." Hal tersebut menunjukkan bahwa syeikh Ja'far memulai penulisan kitab dengan menyebut nama Allah serta puji-pujian kepada-Nya dengan harapan mendapat keberkahan dari kitab yang ditulis yaitu kitab Al Barzanji. Selain itu, dengan mengucapkan basmallah akan dapat menyempurnakan keberkahan pada setiap amal seorang hamba. Imam Nawawi (2015:10) menceritakan:

Imam Atha' dari imam jabir bin Abdillah, beliau berkata: "Ketika Allah menurunkan kalimat bismillahirrahmanirrahim mendung berlarian ke arah timur, angin pun berhenti bertiup, laut pun bergejolak, hewan-hewan pun menegakkan telinga, setan dilemparkan dari langit, dan 
Allah Azza Wa Jalla bersumpah "tidak akan disebut nama-Nya atas orang sakit kecuali dia akan disembuhkan, tidak akan disebut nama-Nya pada sesuatu kecuali diberkahi, dan siapapun yang membaca bismillahirramanirrahim akan masuk surga.

Cerita tersebut menunjukkan bahwa sebagai manusia yang beriman segala aktivitas-aktivitas ataukegiatan adalah sarana menebar kebajikan, baik dalam perkataanmaupun perbuatan selalu memberikan kebaikan pada diri pribadi dan oranglain. Karena agama Islam adalah agama penebar kebaikan. Jika setiap perbuatan baik tidak di awali dengan menyebut nama Allah, maka akan kurang keberkahan, walaupun hal ini terlihat mudah, tapi kenyataannya masih banyak diantara manusia lalai dari mengingat Allah. Oleh sebab itu bagi seorang muslim seyogyanya selalu menyertakan Allah dalam segala amal perbuatan, niscaya akan bertambah terus kebaikan pada diri pribadi.

Dari uraian di atas dapat dipahami bahwa nilai pendidikan akhlak dalam bait kitab Al Barzanji syeikh Ja'far mengajarkan kepada umat Islam agar memulai segala sesuatu amal dengan menyebut Allah SWT. terutama berkaitan dengan konteks dunia pendidikan. Selama proses kegiatan belajar mengajar baik guru ataupun siswa harus sama-sama memulai pembelajaran dengan berdoa minimal membaca bismillahirrahmanirrahim dan menutup pembelajaran dengan mengucapkan hamdallah, sehingga dengan hal itu bisa menjadi sebab keberkahan ilmu yang telah diperoleh.

\section{Sikap Bersyukur}

Syukur merupakan nilai-nilai yang terkandung dalam akhlak Islamiyah. Nilai akhlak kepada Allah yaitu syukur terdapat dalam berbagai syair pada kitab Al Barzanji seperti pada kalimat berikut:

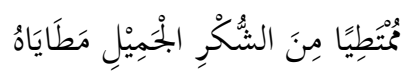

Artinya: Dengan mengendarai sekedup dari syukur yang indah.(Zuhri, 2012:8).

Berkaitan isi bait kitab Al Barzanji tersebut, Imam Nawawi (2015:11) menjelaskan bahwa "Lafaz syukursecara bahasa itu sinonim dari lafaz hamd secara istilah yaitu perkara yang menunjukkan mengagungkan orang yang diberi nikmat karena sebab dia diberi nikmat oleh dari orang yang bersyukur". Sama halnya seseorang bersyukur dengan lisan atau rasa cinta dalam hati atau dengan mengkhidmatkan anggota badan. Adapun syukur menurut istilah adalah menggerakkan seorang hamba kepada seluruh anggota badan yang diberi nikmat oleh Allah diantaranya dari pendengaran dan lain-lain kepada hal yang semestinya.

Syukur merupakan sikap seseorang untuk tidak menggunakan nikmat yang diberikan oleh Allah SWT. dalam maksiat kepada-Nya. Bentuk syukur ini ditandai dengan keyakinan hati bahwa nikmat yang diperoleh berasal dari Allah SWT., bukan selain-Nya, lalu diikuti pujian lisan, dan tidak menggunakan nikmat tersebut untuk sesuatu yang dibenci pemberian. Bentuk syukur terhadap nikmat yang Allah SWT. berikan tersebut adalah dengan jalan mempergunakan nikmat Allah SWT. itu dengan sebaik-baiknya. Adapun karunia yang diberikan oleh Allah SWT. harus kita manfaatkan dan kita pelihara, seperti panca indra, harta benda, ilmu pengetahuan dan lain sebagainya.

\section{Doa}

Doa merupakan salah satu syariat yang mesti diamalkan oleh setiap muslim. Berdoa diperintahkan oleh Allah dalam Al Qur'an dan Rasulullah dalam Al Hadits. Perintah berdoa sendiri hukum asalnya adalah wajib kecuali ada dalil yang menerangkan ketidakwajibannya.

Doa merupakan salah satu bentuk akhlak terpuji kepada Allah SWT. Nilai akhlak kepada Allah berupa doa dalam kitab Al Barzanji dapat dijumpai sebagai berikut:

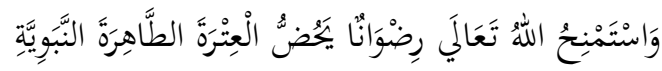

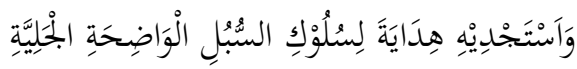

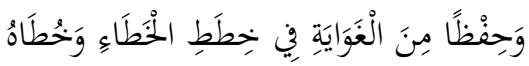

Artinya:

Dan aku memohon pemberian Allah SWT berupa keridloan yang husus untuk para keluarga Nabi SAW yang suci. 
Dan saya memohon hidayah, agar kita semua dapat menempuh jalan yang sudah jelas dan terang.

Saya memohon perlindungan, agar terpelihara dari kesalahankesalahan dan derap langkahnya dalam penulisan kisah ini (Zuhri, 2012:9).

Nilai akhlak kepada Allah berupa doa sebagaimana terdapat pada kitab Al Barzanji berarti memohon pemberian dari Allah SWT yaitu berupa ridha yang dikhususkan kepada keluarga Nabi SAW yang suci dari syirik dan hal-hal yang kotor dan keridhoan itu juga meliputi kepada para sahabat yaitu orang-orang yang berkumpul dengan Nabi semasa hidup setelah Nabi diutus dalam keadaan beriman kepada-Nya, walaupun tidak lama berkumpul dengannya dan meninggal dalam keadaan beriman dan kepada para tabi'in yaitu orang-orang yang berkumpul dengan para sahabat dan orang-orang setelahnya yang memuliakan dan mencintai Nabi SAW. Berdoa berarti memohon pemberian hidayah dari Allah untuk menempuh jalan yaitu hukum-hukum syariat yang beramal dengannya menjadi sebab sampai kepada surga dan jalan-jalan itu merupakan jalan yang jelas yang terbuka dari sebuah kesamaran. Nawawi (2015:5) mengatakan, "Dan memohon perlindungan kepada Allah SWT dari kesesatankesesatan yaitu lawan dari kebenaran ditempat-tempat kesalahan dan jalan-jalan menuju kesalahan"

Untuk itu, nilai akhlak kepada Allah berupa doa, walaupun secara kualitas doa disejajarkan dengan setengah ibadah wajib, tapi dari segi substansinya doa merupakan inti dari setiap ibadah yang kita lakukan kepada Sang Pencipta. Shalat yang dilakukan terdiri dari kumpulan doa, mulai dari awal takbir sampai salam, begitupun ibadah yang lain. Makanya tidak salah kalau Rasullulah mengatakan bahwa doa adalah ruhnya ibadah. Tanpa doa ibadah tidak akan punya arti apa-apa. Secara mendasar doa merupakan penghancuran nilai-nilai egoisme kemanusiaan yang selalu identik dengan kesombongan, keangkuhan dan merasa bahwa setiap keberhasilan adalah jerih payah sendiri tanpa menganggab adanya campur tangan Allah SWT sebagai zat pengatur. Keberhasilan selalu diidentikkan dengan kecerdasan kognitif semata, kesuksesan selalu dipahami sebagai jerih payah sendiri, disinilah celah tipuan.

\section{Tawakal}

Salah satu bentuk nilai akhlak yang terdapat dalam kitab Al Barzanji adalah tawakal. Amin (2006:53) menjelaskan, "Tawakal berasal dari bahasa Arab تُكُ menyerahkan. Tawakal berarti berserah diri sepenuhnya kepada Allah dalam menghadapi atau menunggu hasil suatu pekerjaan". selain pengertian tersebut, Al Jauziah (2012:73) menjelaskan:

Tawakal adalah amalan dan ubudiyah hati dengan menyandarkan segala sesuatu hanya kepada

Allah, tsiqah terhadap-Nya, berlindung hanya kepada-Nya dan ridha atas sesuatu yang menimpa dirinya, berdasarkan keyakinan bahwa Allah akan memberikannya segala kecukupan bagi dirinya dengan tetap melaksanakan sebab-sebab atau faktor-faktor yang mengarahkannya pada sesuatu yang dicarinya serta usaha keras untuk dapat memperolehnya.

Ajaran tawakal merupakan salah satu bentuk nilai akhlak kepada Allah SWT yang terdapat pada kitab Al Barzanji sebagaimana terdapat pada kalimat berikut:

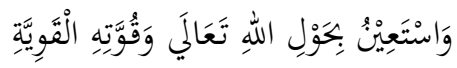

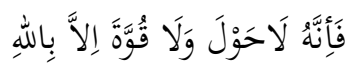

Artinya:

Dan aku minta tolong dengan kekuatan Allah Ta'ala yang sangat kuat

Karena tiada daya dan upaya selain dengan Allah SWT (Zuhri, 2012:10).

Berkaitan nilai tawakal pada kitab Al Barzanji tersebut, An Nawawi (2015:5) menjelaskan pengertian tawakal sebagai berikut:

Dan aku meminta pertolongan dengan kekuasaan Allah dan kekuatan yang sempurna, maka sesungguhnya tidak ada daya untuk menghindari dari maksiat dan tidak ada kekuatan untuk melakukan taat kecuali atas perlindungan dan pertolongan-Nya.Hakikat tawakal adalah menyerahkan segala urusan kepada Allah Azza wa Jalla, membersihkan dari ikhtiar yang keliru, dan tetap menapaki kawasan-kawasan hukum dan ketentuan. Dengan demikian, hamba percaya dengan bagian Allah SWT untuknya. Apa yang telah ditentukan Allah SWT. untuknya, ia yakin 
pasti akan memperolehnya. Sebaliknya, apa yang tidak ditentukan Allah SWT untuknya, ia pun yakin pasti tidak akan memperolehnya.

Penjelasan tersebut menunjukkan bahwa tawakal merupakan gambaran keteguhan hati dalam menggantungkan diri hanya kepada Allah SWT. Al Ghazali (t.t.:83) mengaitkan tawakal dengan tauhid dengan penekanan bahwa tauhid sangat beerfungi sebagai landasan tawakal. Tawakal mempunyai hubungan yang sangat erat dengan pemahaman manusia akan takdir, rida, ikhtiar, sabar, dan doa. Tawakal merupakan kesungguhan hati dalam bersandar kepada Allah SWT untuk mendapatkan kemaslahatan serta mencegah kemudharatan, baik menyangkut urusan dunia maupun urusan akhirat.

\section{B. Akhlak kepada Makhluk Allah}

Akhlak kepada mahluk merupakan sikap atau perilaku yang melekat pada diri seseorang secara spontan yang dilakukan terhadap sesama makhluk khususnya manusia. Akhlak kepada makhluk menurut sifatnya terbagi menjadi dua yaitu mahmudahdanmadzmumah. Akhlak kepada mahluk yang terdapat pada kitab Al Barzanji dapat diuraikan sebagai berikut:

\section{Akhlak Kepada Rasulullah SAW}

Disamping akhlak kepada Allah SWT, setiap muslim juga harus berakhlak kepada Rasulullah SAW. Meskipun Rasulullah SAW sudah wafat dan umat Islam sekarang tidak berjumpa dengan beliau, namun keimanan kepadanya membuat umat Islam harus berakhlak baik kepadanya, sebagaimana keimanan kepada Allah SWT membuat umat Islam harus berakhlak baik kepada-Nya. Meskipun demikian, akhlak baik kepada Rasul pada masa sekarang tidak bisa diwujudkan dalam bentuk lahiriah atau jasmaniah secara langsung sebagaimana para sahabat telah melakukannya. Nilai akhlak kepada Rasul SAW pada kitab Al Barzanji terdapat pada kalimat berikut:

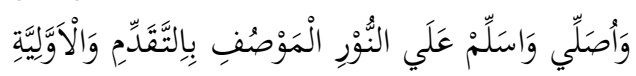

Artinya:

Dan saya bersholawat dan salam semoga tetap atas Nabi Muhammad, pribadi yang memiliki pancaran nur qadim dan abadi(Zuhri, 2012:8).

Ungkapan Ja'far Al Barzanji pada kitab Al Barzanji di atas merupakan salah satu bait pembuka dalam kitab Al Barzanji. Syeikh Ja'far memulai penulisan kitab dengan pembacaan shalawat kepada Nabi SAW. setelah sebelumnya mengucapkan puji-pujian kepada Allah SWT sebagaimana ungkapan berikut:

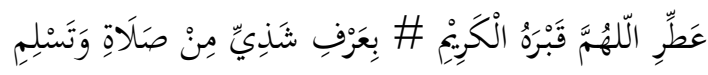

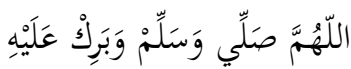

Artinya:

Semoga Allah mengharumkan dan mewangikan kubur-nya (Nabi) yang mulia, dengan keharuman wangi-wangian shalawat dan salam sejahtera. Ya Allah, berilah shalawat dan salam serta berkah atas Nabi SAW (Zuhri, 2012:10).

Bait di atas merupakan bait yang selalu ada di setiap penutup bab dalam kitab Al Barzanji. Isi dari bait tersebut adalah doa dan shalawat kepada Nabi Muhammad SAW.

\section{Akhlak Kepada Diri Sendiri}

Selain berakhlak kepada orang lain, seorang muslim harus berakhlak kepada diri sendiri. llyas (2007:44) menjelaskan, "Akhlak terhadap diri sendiri adalah sikap seseorang terhadap diri pribadinya baik itu jasmani sifatnya atau rohani". Penjelasan tersebut menunjukkan bahwa seseorang harus adil dalam memperlakukan diri pribadi dan jangan pernah memaksa diri untuk melakukan sesuatu yang tidak baik atau bahkan membahayakan jiwa. Sesuatu yang membahayakan jiwa bisa bersifat fisik atau psikis. Misalnya seseorang melakukan hal-hal yang bisa membuat tubuh menderita. Seperti terlalu banyak bergadang, sehingga daya tahan tubuh berkurang, merokok, yang dapat menyebabkan paru-paru kita rusak, mengkonsumsi obat terlarang dan minuman keras yang dapat membahyakan jantung dan otak. Untuk itu kita harus bisa bersikap atau beraklak baik terhadap tubuh. Selain itu sesuatu yang dapat membahayakan diri, halitu bisa bersifat psikis. Misalkan iri, dengki, munafik dan lain sebagainya. Hal itu semua dapat 
membahayakan jiwa, semua itu merupakan penyakit hati yang harus dihindari. Hati yang berpenyakit seperti iri dengki munafiq dan lain sebagainya akan sulit sekali menerima kebenaran, karena hati tidak hanya menjadi tempat kebenaran, dan iman, tetapi hati juga bisa berubah menjadi tempat kejahatan dan kekufuran.

Akhlak kepada diri sendiri dalam kitab Al Barzanji sangat beragam diantaranya adalah:

a. Tawadhu'

Nilai akhlak kepada diri sendiri melalui sikap tawadhu disebutkan dalam kitab Al Barzanji sebagai berikut:

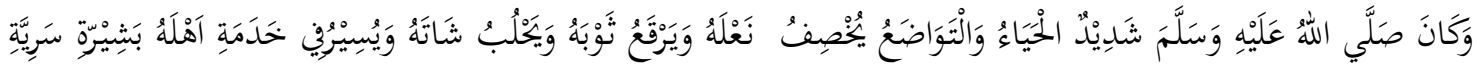

Artinya:

Beliau SAW. adalah seorang yang sangat pemalu, dan tawadhu, mau memperbaiki terompahnya sendiri, dan mau menambal pakaiannya sendiri, mau memerah kambingnya, dan mau membantu keperluan dalam rumah tangganya (Zuhri, 2012:22).

b. Benar dan Jujur

Sikap jujur merupakan salah satu bentuk nilai akhlak yang dijelaskan pada kitab $A$ l Barzanji dengan mengungkapkan sikap jujur Nabi Muhammad SAW sebagai berikut:

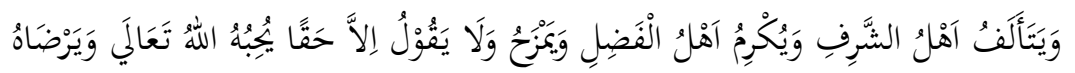

Artinya:

Beliau menyukai orang yang mulia, menghormati orang yang utama, bersenda gurau dengan sahabat-sahabatnya. Dan beliau tidak pernah berbicara melainkan yang benarbenar saja, yang disukai Allah Ta"ala dan diridhai-Nya (Zuhri, 2012:21).

c. Sabar

Nilai akhlak kepada diri sendiri berupa sikap sabar terdapat dalam kitab Al Barzanji sebagai berikut:

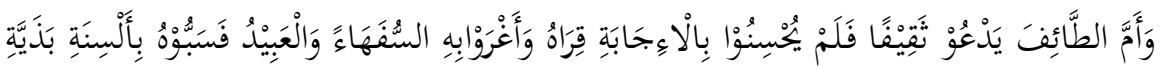

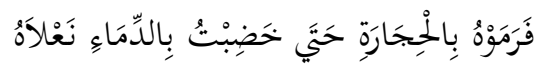

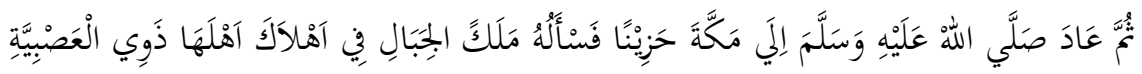

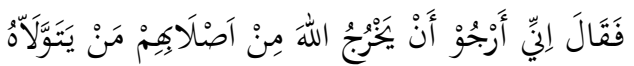

Artinya:

Kemudian pada suatu saat, Nabi SAW berangkat menuju Thoif dengan tujuan memberi da"wah kepada suku Tsaqif, namun mereka tidak mengindahkan ajakan beliau dan bahkan mereka menyuruh para budak dan anak-anak kecil agar mencacinya

Dan melemparkan batu padanya sampai sandal beliau terkena darah dari kakinya.

Kemudian Nabi SAW kembali ke Makkah dengan di liputi kesusahan, lalu beliau di temui Malaikat yang mengurusi gunung dan menawarkan padanya untuk menghancurkan mereka yang memilki fanatisme jahiliyyah.

Namun beliau menjawabnya, Aku berharap Allah akan mengeluarkan dari mereka anakanak yang di kasihi oleh-Nya (Zuhri, 2012:37)

d. Iffah (Memelihara Kesucian Diri)

Sikap iffahmerupakan bentuk akhlak kepada diri sendiri yang mendapat penekanan dalam kitab Al Barzanji sebagaimana syair berikut:

$$
\text { تَرَكُوْا السِّفَاحُ فَلَمْ يُصِبْهُمْ عَارُهُ }
$$

Artinya:

Mereka meninggalkan perzinaan, maka cacat perzinaan itu tidak menimpa mereka.

Dari Adam sampai ayah ibunya (Zuhri, 1992:16) 
e. Kesederhanaan

Pakaian beliau tidak lebih bagus dari yang lain. Beliau bergaul dengan siapa pun, kaya maupun miskin. Hal tersebut diterangkan dalam kitab Al Barzanji sebagai berikut:

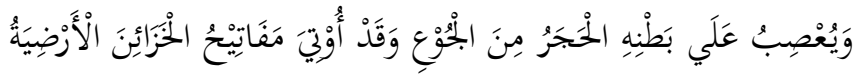

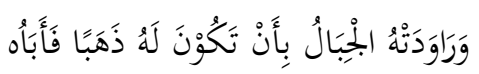

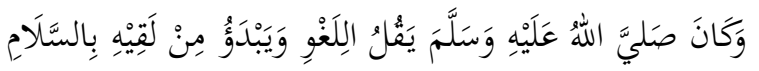

Artinya:

Untuk mengurangi rasa lapar, beliau seringkali membungkus batu dengan kain yang diikatkan pada perutnya. Padahal, kunci gedung perbendaharaan bumi berada di tangannya. Gunung-gunung menawarkan diri untuk dijadikan gunung emas untuk keperluannya, tetapi ditolaknya.

Beliau menyedikitkan hal-hal yang tidak berguna dan beliau memulai salam kepada orang yang bertemu dengannya (Zuhri, 2012:19)

\section{Akhlak Terhadap Keluarga}

a. Berbuat Baik Kepada Orang Tua (Birrul Walidain)

Nilai akhlak berbakti kepada orang tua dalam kitab Al Barzanji disebutkan:

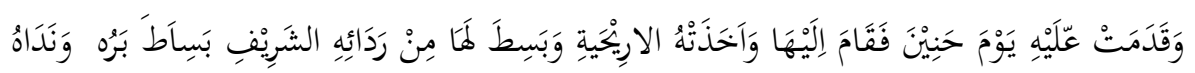

Artinya:

Dan di saat terjadi perang Hunain, ibu Halimah juga perna menemui Nabi SAW. Lalu beliau menghormatinya dengan pemberian dan mempersilahkan duduk di atas selendang yang sengaja beliau gelar untuknya (Zuhri, 2012:24).

b. Akhlak kepada Anak

Al Ja'far dalam kitab Al Barzanjimengungkapkan sebagai berikut:

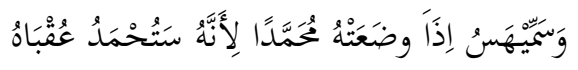

Artinya:

Bila engkau telah melahirkannya, berilah nama pada Muhammad, karena dia akan dipuji kesudahannya (Zuhri, 2012:31)

Kutipan tersebut mengandung nilai pendidikan bagi orang tua khususnya ketika sudah mempunyai anak. Hal yang pertama harus dilakukan adalah memberikan nama yang baik untuk anak tersebut, karena nama merupakan sebuah doa. Orang tua memberikan nama baik seperti nama Muhammad kepada anaknya itu berharap agar ketika dewasa nanti menjadi orang yang berakhlak terpuji.

\section{Akhlak dalam Masyarakat}

Nilai-nilai akhlak dalam bermasyarakat yang terdapat pada kitab Al Barzanji dapat diuraikan sebagai berikut:

a. Musyawarah berikut:

Nilai akhlak berupa musyawarah diajarkan secara jelas dalam kitab Al Barzanji sebagai

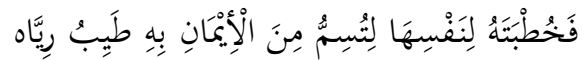

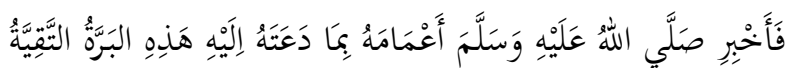

Artinya:

Kemudian khadijah melamarkan dirinya, dengan maksud agar ia dapat merasakan bau iman dan kesegarannya.

Maka beliau saw. memberitahukan maksud khadijah itu kepada paman-pamannya untuk b. Adil dimintai pertimbangan (Zuhri, 2012:36)

Sikap adil merupakan nilai akhlak yang dijarkan dalam kitab Al Barzanji sebagai berikut:

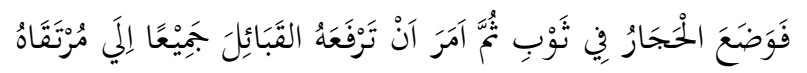


Artinya:

Kemudian beliau meletakkan Hajar Aswad tersebut di atas sebuah kain dan memerintahkan kepada semua suku agar mengangkatnya ke tempatnya semula (Zuhri, 2012:37)

c. Kasih Sayang

Islam pun mengatur batas-batas atau bentuk kasih sayang yang diperbolehkan dalam Islam sebagaimana ajaran nilai akhlak dalam kitab Al Barzanji sebagai berikut:

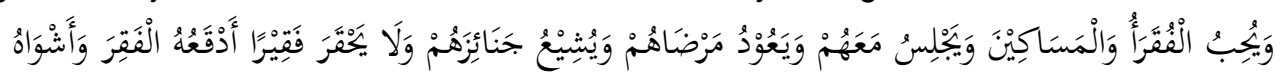

Artinya:

Beliau menyukai orang fakir dan miskin, dan suka duduk bersama-sama mereka, mau mengantarkan jenazah mereka, dan tidak mau menghinakan orang fakir, betapapun miskin d. Pemaaf dan melaratnya orang itu (Zuhri, 2012:39)

Nilai-nilai akhlak bermasyarakat yaitu pemaaf terdapat dalam kitab Al Barzanji sebagai berikut:

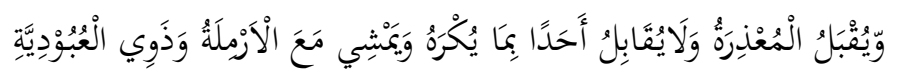

Artinya:

Beliau suka memberi maaf, dan tidak pernah menghadapinya dengan sikap yang membencikan, dan mau berjalan dengan orangorang yang lemah dan para budak belian (Zuhri, 2012:41)

\section{Pembahasan}

Manusia merupakan makhluk yang senantiasa bergerak dinamis. Sebagai makhluk yang ditakdirkan sebagai abdi Tuhan dan sekaligus pelaksana kehendak Tuhan di muka bumi tak sedikit dinamika mausia mengalami gesekan. Kemudian gesekan tersebut tidak selamanya mengarah pada hal yang positif, akan tetapi berbalik negatif. Pendidikanlah yang akan mengantar manusia pada derajat insan kamil, sempurna secara akal dan sempurna secara moral.

Pendidikan dapat ditinjau dari dua sudut pandang. Langgulung (2002:3) menjelaskan dua sudut pandang pendidikan sebagai berikut:

Dari sudut pandang masyarakat, pendidikan merupakan pewarisan kebudayaan dari generasi tua ke generasi muda agar hidup masyarakat berkelanjutan. Atau dengan kata lain, masyarakat mempunyai nilai-nilai budaya yang ingin disalurkan dari generasi ke generasi agar identitas masyarakat tersebut tetap terpelihara. Sedang bila dilihat dari kaca mata individu pendidikan berarti pengembangan potensipotensi yang terpendam dan tersembunyi. Individu itu laksana lautan dalam yang penuh mutiara dan bermacam-macam ikan, tetapi tidak nampak. la masih berada didasar laut. la perlu dipancing dan digali supaya menjadi makanan dan perhiasan bagi manusia

Nilai-nilai pendidikanakhlak yang penulis temukan di dalam kitab Al Barzanji dapat diimplementasikan dalam pendidikan guna pembentukan pribadi Islami. Implementasi nilai-nilai akhlak dalam kitab Al Barzanji dalam pendidikan dapat diuraikan berikut:

\section{A. Akhlak Kepada Allah}

Akhlak pertama kepada Allah adalah mencintai Allah sebagai Tuhan yang patut di sembah. Rasa kecintaan kepada Allah merupakan bentuk nilai akhlak yang dapat diimplementasikan dalam pendidikan. Hal tersebut sebagaimana terdapat dalam Permendikbud nomor 24 yang telah dirumuskan tentang kompetensi sikap spiriual yakni diharapkan peserta didik mampu menghayati dan menjalankan ajaran agama yang dianutnya. Oleh karena itu, era modern saat ini, di tengah kemajuan teknologi seorang manusia sudah banyak yang lalai dan jauh dari Allah, sudah lebih banyak mencintai dunia sehingga dirumuskan di dalam Permendikbud nomor 24 tahun 2016.

Akhlak kedua kepada Allah adalah senantiasa berdoa. Doa adalah memohon atau meminta pertolongan kepada Allah SWT akan tetapi bukan berarti hanya orang-orang yang sedang ditimpa musibah saja yang layak memanjatkan doa. Dalam keadaan lapang ataupun tidak memiliki kekurangan atas sesuatu sebagai seorang muslim sangat layak untuk berdoa seperti berdoa untuk mengampunkan segala dosa dan kesalahan, memohon perlindungan Allah SWT memohon keridhaan Allah SWT dan lain-lain. 
Tentang syukur, sikap syukur atas segala ketentuan dari Allah SWT akan membuahkan nilai akhlak yaitu tawakal. Tawakal adalah menyandarkan hati kepada Allah ketika mencari maslahat atau menghindari mudhorot dalam perkara duniawi maupun ukhrawi. Al Mishri (2000:3) mengemukakan, "Mukmin yang bertawakal akan menyerahkan segala urusannya kepada Allah SWT dan mewujudkan keimanannya dengan menyakini bahwa Allah yang mampu memberi atau tidak memberi sesuatu dan mendatangkan manfaat atau mara bahaya". Tawakal bukanlah pasrah tanpa berusaha, namun harus disertai dengan ikhtiar. Tawakal merupakan bentuk dari usaha terakhir bagi orang mukmin dalam menghadapi segala macam masalah dalam hidup. Ikhtiar dilakukan dengan anggota-anggota tubuh sedangkan tawakkal dilakukan oleh hati. Jika sebuah ikhtiar tanpa disertai dengan tawakkal bisa dikatakan dengan hamba yang sombong, sedangkan jika tawakkal tanpan disertai dengan ikhtiar akan sia-sia. Nilai tawakkal yang dijelaskan dalam kitab Al Barzanji di atas bahwa Allah SWT yang mempunyai segala kekuatan, karena tidak ada kekuatan lain selain kekuatannya, maka sebagai seorang makhluk yang tidak mempunyai daya untuk menghindari diri dari maksiat, dan juga tidak ada kekuatan untuk melakukan ketaatan kecuali atas perlindungan dan pertolongan-Nya. Oleh karena itu Syeikh Ja'far mengajarkan agar selalu menggantungkan diri kepada-Nya dan meminta pertolongan hanya kepada-Nya

\section{B. Akhlak Kepada Makhluk}

Akhlak kepada makhluk yang paling utama adalah akhlak kepada Rasul SAW. Untuk membuktikan akhlak kita kepada Rasul ialah dengan meneladani dan mencontohnya. Rasul penuntun manusia seluruh dunia, tetapi bukan untuk pamer, berbangga-bangga dan bukan pula untuk alat mencari pangkat, jabatan dengan cara mempertontonkan datang ke Masjid.

Nilai akhlak kepada makhluk kedua yang terdapat pada kitab Al Barzanji adalah akhlak kepada diri sendiri yaitu bersikap tawadhu, jujur, sabar, iffah, dan bersikap sederhana. Berkaitan dengan implementasi nilai tawadhu, di dalam Permenag nomor 912 telah dirumuskan tentang kompetensi sikap sosial yakni diharapkan peserta didik mampu menghayati dan mengamalkan perilaku jujur, disiplin, tanggung jawab, peduli, (gotong royong, kerjasama, toleran, damai), santun, percaya diri, dalam berinteraksi secara efektif dengan lingkungan sosial dan dalam jangkauan pergaualan dan keberadaannya.Nilai tawadhu sangat penting dan relevan untuk dibentuk pada pribadi seorang peserta didik agar terhindar dari sifat yang dibenci oleh Allah SWT yaitu takabur.

Nilai tawadhu yang ada pada diri setiap individu maka akan terbentuk satu nilai akhlak lain yaitu jujur. Sikap jujur merupakan sifat yang harus dimiliki oleh seorang muslim. Dalam kitab Al Barzanji Syeikh Ja'far menjelaskan sifat Nabi Saw. yang mulia yakni Jujur, bahwasanya Nabi SAW. tidak pernah berkata kecuali dengan perkataan-perkataan yang benar saja, yang disukai Allah dan diridhai oleh-Nya sampai beliau mendapat gelar Al-Amin di masyarakat arab saat itu. Hal ini mengajarkan kepada kita agar selalu berlaku jujur dalam kehidupan sehari-hari.

Kejujuran pada diri setiap individu akan membentuk dan mengembangkan nilai akhlak lain yaitu sikap sabar. Sabar itu adalah menahan diri dari dorongan hawa nafsu demi menggapai keridhaan Tuhannya dan menggantikannya dengan bersungguh-sungguh menjalani cobaan-cobaan dari Allah SWT. terhadapnya. Sabar dapat didefinisikan pula dengan tahan menderita dan menerima cobaan dengan dengan hati ridha serta menyerahkan diri kepada Allah SWT. setelah berusaha. Selain itu, sabar bukan hanya bersabar terhadap ujian dan musibah, tetapi juga dalam hal ketaatan kepada Allah SWT., yaitu menjalankan perintah-Nya dan menjauhi larangan-Nya.

Berikut merupakan cara-cara agar menjadi pribadi yang penyabar, yaitu:

1. Harus menyadari bahwa hakikat kehidupan adalah ujian, dan sebaik-baiknya orang yang mendapat ujian tersebut adalah orang yang bersabar.

2. Harus meyakini bahwa ujian ini adalah cara Allah dalam mendidik manusia agar menjadi pribadi yang lebih baik.

3. Harus meyakini bahwa ketika Allah memberikan ujian dan cobaan kepada manusia, pasti Allah akan memberikan kekuatan untuk menghadapi ujian dan cobaan tersebut karena Allah tidak akan menguji seseorang diluar batas kemampuan orang tersebut.

4. Selalu memotivasidiri bahwa Allah selalu menyertai atau bersama orang-orang yang sabar.

Nilai pendidikan akhlak lain dalam kitab Al Barzanji yang dapat diimplementasikan dalam pendidikan adalah sikap iffah atau menjaga kehormatan. Iffah hendaklah dilakukan setiap waktu agar 
tetap berada dalam keadaan kesucian. Hal ini dapat dilakukan dengan mulai menjaga hati untuk tidak membuat rencana dan angan-angan yang buruk. Dan kesucian diri (iffah) ada bermacam-macam yakni antara lain:

1. Kesucian lisan, yakni dengan menjaga lisan dari ucapan-ucapan yang dilarang oleh Allah seperti: berkata kasar kepada orang tua, teman, tetangga dan lain-lain.

2. Kesucian tubuh, yakni dengan menutup aurat, menjauhi perbuatan zina dan lain-lain.

3. Kesucian pandangan, yakni dengan menjaga pandangan dari hal-hal yang dilarang oleh agama seperti melihat aurat lawan jenis dan lain sebagainya.

\section{Akhlak Kepada Keluarga}

Di antara sifat orang muslim yang paling menonjol adalah berbakti dan berbuat baik kepada kedua orang tua (Birrul walidain). Yang demikian itu karena berbakti kepada keduanya merupakan sesuatu hal yang amat besar dan sangat ditekankan dalam Islam, serta telah ditegaskan melalui nash-nash yang pasti (qath"i). Berikut di bawah ini adalah beberapa cara untuk berbakti kepada orang tua:

1. Memberikan penghormatan dan memuliakan kedua orang tua.

2. Berdiri jika keduanya berdiri dari tempat duduknya dan menundukkan kepada sembari mencium tangan keduanya.

3. Merendahkan diri serta berbicara lemah lembut kepadanya. Sehingga tidak ada kata-kata yang menyakitkan kedua orang tua.

4. Tidak memperlakukannya dengan sesuatu yang menjadikan keduanya mendapatkan aib.

5. Mendoakannya ketika keduanya telah meninggal.

Berdasarkan pemaparan di atas nilai akhlak berbakti kepada orang tua tentunya masih sangat relevan untuk dijadikan acuan atau tolak ukur kepribadian seorang muslim, karena bagaimanapun juga walaupun seorang muslim sudah mempunyai sifat jujur, ikhlas, pemaaf dan lain-lain tapi ia tidak berbakti kepada keduaorang tuanya maka hal itu akan menjadi sia-sia

Berbakti kepada orang tua akan berbanding terbalik dengan akhlak kepada seorang anak. Seperti yang di jelaskan dalam kitab al-Barzaji bahwa ketika lahir seorang anak maka berilah ia nama Muhammad, maksud dari penjelasan tersebut bahwa ketika lahir seorang anak berilah ia nama-nama yang baik karena dari nama yang baik diharapkan ketika dewasa kelak menjadi pribadi yang baik pula. Dalam hal akhlak terhadap anak, ada beberapa cara yang dilakukan orang tua kepada anak. Antara lain:

1. Berikan nama yang Islami, yakni nama-nama baik pada anak, seperti nama-nama para nabi, ulana dan orang-orang sholeh.

2. Mendidik anak dengan penuh kasih sayang.

3. Memberikan rizki yang halal dan baik kepada anak, karena makanan dan minuman yang ia makan akan mempengaruhi kepribadian anak.

4. Memberikan pendidikan yang baik kepada anak.

5. Menanamkan akhlak al-karimah kepada anak.

6. Berlaku adil kepada anak.

D. Akhlak Kepada Masyarakat

Dasar kehidupan bermasyarakat paling utama yang harus diimplementasikan dalam pendidikan adalah nilai-nilai kasih sayang. Seorang muslim yang mengamalkan hukum-hukum agamanya selalu bersikap toleran karena ilmunya, menyebarkan kasih sayang dan memancarkan sumber kasih sayang dari hatinya. Dan menyadari bahwa kasih sayang seseorang hamba di bumi menjadi sebab datangnya rahmat dari langit. Pada dasarnya agama Islam adalah agama kasih sayang, oleh karnanya wajib bagi setiap pribadi seorang muslim memiliki pribadi yang penuh dengan kasih sayang.

Nilai dasar keadilan adalah nilai-nilai akhlak terpuji dalam bermusyawarah. Ibnu al Arabi (dalam Anwar, 2013:66) menjelaskan bahwa "Musyawarah itu lebih dapat mempersatukan orang banyak, lebih membuka pikiran, dan merupakan sebab untuk sampai pada kebenaran. Tidaklah suatu kaum bermusyawarah sekalipun kecuali mereka akan diberi petunjuk."Dalam bermusyawarah untuk menyelesaikan permasalahan yang dihadapi harus berdasarkan nilai-nilai akhlak Islami antara lain:

1. Berbicara dengan bijak dan santun ketika hendak menyampaikan saran, gagasan atau ide.

2. Hendaklah untuk berendah hati dan lemah lembut. 
3. Hendaklak memilki sifat pemaaf, karena bisa jadi dalam bermusyawarah terlontar kalimat-kalimat yang menyinggung dan membuat orang sakit hati.

4. Bermusyawarah dengan ikhlas.

5. Bermusyawarah untuk memutuskan kebenaran.

6. Berserah diri kepada Allah SWT atas apapun hasil yang diperoleh berdasarkan musyawarah.

\section{SIMPULAN}

\section{PENUTUP} berikut:

Berdasarkan analisis data yang telah dilakukan, maka dapat disimpulkan hasil penelitian sebagai

1. Konsep pendidikan akhlak adalah suatu kegiatan yang dilakukan secara sadar dan disengaja untuk memberikan bimbingan, baik jasmani maupun rohani, melalui penamaan nilai-nilai islam, latihan moral, fisik serta menghasilkan perubahan ke arah positif, yang nantinya dapat diaktualisasikan dalam kehidupan, dengan kebiasaan bertingkah laku, berfikir dan berbudi pekerti luhur menuju terbentuknya manusia yang berakhlak mulia, dimana dapat menghasilakan perbuatan atau pengalaman dengan mudah tanpa harus direnungkan dan disengaja atau tanpa adanya pertimbangan dan pemikiran.

2. Nilai-nilai pendidikan akhlak yang terkandung dalam kitab Al Barzanji karya Syaikh Ja'far Al Barzanjisecara garis besar terbagi menjadi dua bagian, yakni akhlak kepada Allah SWT dan akhlak kepada makhluk. Akhlak kepada Allah meliputi cinta kepada Allah SWT, syukur, berdoa, dan tawadhu, kedua, akhlak kepada makhluk meliputi akhlak kepada Nabi Muhammad SAW, akhlak terhadap diri sendiri meliputi tawadhu, jujur, sabar, iffah dan zuhud, akhlak kepada keluarga meliputi birrul walidain dan akhlak kepada anak, akhlak kepada masyarakat terdiri atas musyawarah, adil, kasih sayang dan pemaaf.

3. Implementasi nilai-nilai pendidikan akhlak dalam kitab Al Barzanji karya Syaikh Ja'far Al Barzanji dalam pendidikandilakukan melalui penerapan kompetensi inti setiap satuan pembelajaran khususnya kompetensi relegius dan kompetensi sosial.

\section{SARAN}

1. Bagi Peneliti

Berdasarkan hasil penelitian yang telah dilaksanakan, maka dapat disarankan sebagai berikut:

Peneliti selanjutnya hendaknya dapat menjadikan hasil penelitian ini sebagai modal awal pengembangan khasanah keilmuan dan sebagai modal dasar guna penelitian lebih lanjut. Selain itu, penelitian ini dilaksanakan untuk mengembangkan ilmu yang diperoleh sebagai alternatif pelaksanaan salah satu tri darma perguruan tinggi bidang penelitian. Adapun hasil dari kegiatan penelitian kajian ini dapat dijadikan sebagai dasar pengembangan pemikiran Pendidikan Agama Islam dalam upaya membentuk akhlakdankepribadiansiswa.

2. Bagi Guru

Setiap guru yang mengimplementasikan kurikulum 2013 harus mampu menyajikan materi pada $\mathrm{KD}$ di $\mathrm{KI} 3$ dan proses pembelajaran pada KD di KI 4 yang mengarah pada pencapaian KD pada KI 1 dan 2 tanpa mengajarkan secara langsung. Guru serta merta menjadi ujung tombak untuk mencapai kompetensi sikap spiritual dan sosial pada diri setiap siswa. Dengan demikian, maka berbagai nilai-nilai khususnya nilai akhlak sebagaimana yang terdapat dalam kitab Al Barzanji dapat diimplementasikan secara baik.

3. Bagi Masyarakat

Hasil penelitian hendaknya dapat menyadarkan masyarkat akan arti penting penanamannilainilaiakhlakPendidikan Agama Islam. Hendaknya bagi setiap muslim yang mengamalkan pembacaan kitabmaulid AlBarzanji untuk mengkaji arti maupun makna kitab tersebut, agar lebih membekas dalam diri dan semakin cinta kepada Nabi MuhammadSAW.Untuk para pemuka agama baik Habaib, Ustadz maupun Kiai agarmemberikan pengertian dan pemahaman kepada masyarakat ataskandungan yang terdapat dalam kitab AlBarzanji ini baik pada saatperayaan-perayaan maulid, pengajian-pengajian, dan lain-lain yangdiadakan di masyarakat. 
4. Bagi Lembaga Perguruan Tinggi

Pihak Perguruan tinggi hendaknya dapat mengarahkan para mahasiswa untuk melakukan berbagai analisis terhadap konsep tokoh-tokoh pendidikan guna merekonstruksikan pengetahuan baru yang inovatif. Hasil kegiatan penelitian kajian ini dapat memperkaya wacana pengetahuan seluruh civitas academika kampus. Selain itu, hasil dari kegiatan penelitian diharapkan dapat menambah perbendaharaan kepustakaan kampus.

\section{DAFTAR PUSTAKA}

Abdulrahim, Muhammad Imaduddin. 2002. Islam Nilai Terpadu. Jakarta: Gema Insani

Abdusshomad, Muhyiddin. 2004. Fiqih Tradisional, Jawaban Berbagai Persoalan Keagamaan Sehari-hari. Malang: Pustaka Bayan.

Al Jauziah, Ibnu Qayyim. 2012. Pertarungan Dosa dan Cinta. Jakarta: Media Utama.

Al-Ja'fiy, Imam Abi Abdillah Muhammad ibn Ismail ibn Ibrahim ibn Mughiroh Al-Bukhory. t.t. Shahih Bukhori. Beirut: Dar Al-Fikr.

Al-Attas, Syed Muhammad Naquib. 2002. Haul Ihtifaal bi Dzikra al Maulid an Nabawiy asy-Syarif. Terjm. Abdul Karim. Bandung: LP3IS.

Amin, Muhammad Suma. 2006. Pendidikan Akhlak Masa Kini. Jakarta: Kencana.

An-Najar, Amir. 2011. Ilmu Jiwa Agama. Jakarta: Ar Ruzz Media.

Anwar, Rosihan. 2010. Akhlak Tasawuf. Bandung: Pustaka Setia.

Anwar, Fuad. 2013. Cara Mendidik Ala Rasulullah SAW. Surabaya: Usaha Keluarga.

Arif, Armai. 2002. Metodologi Pengajaran Agama Islam. Jakarta: Raja Grafindo Persada.

Bertens, Ahmad Ismail. 1993. Al Falsafat Al Islamiyyah Syakhshiyatuhu Mazahibuha. Terj. M. Daud Ali. Jakarta:Kaifa.

Dasuki, Usma. 2009. Al Qur"an dan Tafsirnya. Yogyakarta: Dana Bhakti Wakaf.

Dauly, Hamdan. 2003 Dakwah di Tengah Persoalan Budaya dan Politik. Yogyakarta: LESFI.

Dewan Redaksi Ensiklopedi Islam. 1997. Ensiklopedi Islam, Juz I. Jakarta: Ichtiar Baru Van Hoeve

Fatah, Abdul Mubin. 2008. Catatan Kang Jalal Visi Media, Politik, dan Pendidikan, Bandung : PT Remaja Rosdakarya.

Ghazali, Imam. t.t. Ihya' Ulumuddin Juz III. Surabaya: Al Maktab.

Hafidhuddin, Didin. 2006. Agar Layar Tetap Terkembang. Jakarta: Gema Insani.

Hamalik, Oemar. 2010. Proses Belajar Mengajar. Jakarta: Bumi Aksara.

Hasbullah. 2011. Dasar-dasar Ilmu Pendidikan. Jakarta: Rajawali Pers.

Ilyas, Yunahar. 2007. Kuliah Akhlak. Jakarta: Ar Ruzz Media.

Khalifah, Ahmad. 1999. Adventure Parenting;Menjadi Orang Tua Cerdas. Bandung:Wacana IImu.

Langulung, Hasan. 2004. Sejarah Perkembangan Pendidikan Islam. Jakarta: Raja Grafindo Persada. 
Mahmud, Ali Abdul Halim. 2004. At Tarbiyah Al Khuluqiyah. Terjemahan. Abdul Hayyi Al Kattani. Jakarta: Gema Insani Press.

Maraghi, Ahmad Mustafa. 1993. Tafsir al-Maraghi 2. Semarang: Toha Putra.

Muhaimin, Abdul Mudjib. 2003. Pemikiran Pendidikan Islam. Bandung: Trigenda Karya.

Mulyasa, E. 2002. Menjadi Guru Profesional. Bandung: Remaja Rosdakarya.

Murodi, Tajalli. 1988:. Pendidikan Akhlak Bagi Anak. Jakarta: Bulan Bintang.

Musa, Muhammad Yusuf. 2011. Falsafah Al Akhlak Fi Al Islam. Beirut: Dar Al Fikr.

Nata, Abuddin. 2012. Akhlak Tasawuf. Jakarta: Raja Grafindo Persada.

Nawawi, Imam. 2015. Tarbiyatul Khuluq. Terj. Fuad Ihsan. Jakarta: Dakwah Islamiyah. 2002. Nashaih al-'Ibad, terjemahan. Ahmad Abdul Madjid. Surabaya: Mutiara Ilmu.

Permendikbud nomor 24 tahun 2016.

Poerwodarminta, W.J.S. 2011. Kamus Umum Bahasa Indonesia, Edisi Ketiga. Jakarta: Balai Pustaka.

Ramli, Nizar. 2004. Pengembangan Kepribadian Muslim. Semarang: Al Kautsar.

Razak, Naufal. 1973. Membina Akhlak Islami. Jakarta: Bina IImu.

Riduwan. 2011. Dasar-dasar Statistika. Bandung: Alfabeta.

Roqib, Akmal. 2009. IImu Pendidikan dalam Perspektif Islam. Bandung: Remaja Rosdakarya.

Shihab, M. Quraish. 2000:2. Membumikan Al Qur'an. Bandung: Mizan Media Utama.

Sudrajat. 2005. Metode Penelitian Kualitatif. Jakarta: Rineka Cipta.

Suhuf, Sulaiman Ulya. 2003. Manajemen Pendidikan; Mengatasi Kelemahan Pendidikan Islam di Indonesia. Jakarta: Yayasan Obor Wacana IImu.

Sukardi. 2012. Metode Penelitian Kuantitatif dan Kualitatif. Jakarta: Rineka Cipta.

Sukmadinata, Nana Syaodih. 2015. Penelitian Untuk Pendidikan dan Psikologi.Bandung: Remaja Rosdakarya.

Sutarjo. 2005. Pembelajaran Nilai-nilai Karakter Bangsa. Jakarta: Prestasi Pustaka.

Zubaidi. 2015. Akhlak dan Tasawuf. Yogyakarta: Lingkar Media

Zuhri, Mohammad. 2012. Almaulidu Nabawi (Terjemah Al Barzanji). Semarang: Karya Toha Putra.

RestiAyu Nisa ${ }^{1}$, Sholeh Hasan ${ }^{2}$ 